\title{
PROGRAMA BOLSA FAMÍLIA: A CONDICIONANTE SAÚDE REALMENTE EXISTE?
}

Editorial

Historicamente, o Sistema de Proteção Social do Brasil se caracteriza por apresentar uma estrutura dual de seguridade social: aos grupos mais vulneráveis socialmente e não inseridos no mercado de trabalho, destina-se a assistência social, enquanto os trabalhadores inseridos no mercado formal de trabalho vinculam-se à previdência social. As camadas pobres da sociedade brasileira, marcadas pela quase ausência de pressão social e sem posição sócio-ocupacional definida, em alguns momentos históricos, foram beneficiadas, e seu atendimento sempre foi justificado como um ato humanitário ou uma moeda política ${ }^{(1)}$.

Nesse aspecto, destaca-se o Programa Bolsa Família (PBF), como um programa de combate à pobreza, criado através de Medida Provisória n. ${ }^{\circ}$ 132/2003, transformado em Lei n. ${ }^{\circ}$ 10.836/2004 e regulamentado por Decreto n. ${ }^{\circ}$ 5.209/2004. Foi iniciado em outubro de 2003 e constituído através da unificação de quatro programas de transferência de renda: Bolsa Escola, Auxílio-Gás, Bolsa Alimentação e Cartão Alimentação ${ }^{(2)}$.

A gestão do Programa Bolsa Família é descentralizada e compartilhada entre União, estados, Distrito Federal e municípios. Os entes federados trabalham em conjunto para aperfeiçoar, ampliar e fiscalizar a execução. O programa é destinado a famílias em situações de extrema pobreza e pobreza ${ }^{(3)}$.

Desde 2004, o PBF encontra-se vinculado ao Ministério do Desenvolvimento Social e Combate à Fome (MDS), mais especificamente à Secretaria Nacional de Renda de Cidadania (Senarc). A inserção das famílias no programa é feita mediante inscrição no Cadastro Único (CadÚnico), de gestão municipal, do qual são selecionadas, de acordo com os critérios do governo federal para o recebimento do benefício ${ }^{(4)}$.

Uma das questões mais polêmicas sobre os programas de combate à pobreza é $o$ alcance de sua efetividade. Em pesquisa realizada em 2006 ${ }^{(1)}$, em João Pessoa-PB, junto a vinte mães beneficiárias do PBF, os dados evidenciaram que $65 \%$ das mães consideram o benefício um favor do Estado. Os autores também apontaram que a assistência social no Brasil ainda é vista como caridade, implicando em direitos sociais minimizados e insuficientes, não garantindo o seu caráter de universalidade, e que o Bolsa Família se afasta cada vez mais de um princípio universal e da garantia de uma renda mínima sem mecanismos seletivos e burocráticos de acessibilidade.

As condicionalidades do Programa Bolsa Família são responsabilidades relacionadas ao cumprimento de ações nas áreas de saúde, educação e assistência social para melhorar as condições de desenvolvimento familiar, principalmente das crianças e adolescentes. Entretanto, essas condicionalidades assumidas pela família e pelo poder público são: na área da educação, matrícula e frequência de $85 \%$ da carga horária escolar mensal para crianças de 6 a 15 anos, e matrícula e frequência escolar de 75\% para adolescentes de 16 a 17 anos; na área da saúde, calendário de vacinação de menores de sete anos, aferição de peso e estatura, serem examinados conforme o Ministério da Saúde (MS) e acompanhamento de gestantes e nutrizes; na assistência social, fortalecimento do Programa de Erradicação do Trabalho Infantil para crianças e adolescentes de até 15 anos.

\author{
Núbia Maria Uchôa Barbosa ${ }^{(1)}$ \\ Maria Albertina Rocha \\ Diógenes $^{(1)}$ \\ Daniela Gardano Bucharles \\ Mont'Alverne ${ }^{(2)}$
} 1) Universidade de Fortaleza - UNIFOR -
Fortaleza (CE) - Brasil
2) Universidade Federal do Ceará - UFC -
Fortaleza (CE) - Brasil 
O Bolsa Família representa um avanço no campo social, mas se limita quando não atinge sua universalidade nem consegue chegar a todos os que precisam de proteção social $^{(1)}$. Limita-se, também, quando suas condicionalidades determinam que crianças e adolescentes tenham que frequentar escolas públicas, mas não garantem qualidade de ensino; ou quando exigem acompanhamento nas unidades de saúde, mas os profissionais não estão "preparados" para essa função. Superar a pobreza significa ir além dos aspectos burocráticos e seletivos para verdadeiramente atingir a todos, incondicionalmente.

Quando nos referimos aos profissionais de saúde "não preparados" para a função, queremos, na verdade, salientar o que ocorre na prática. Percebe-se, no monitoramento das condicionalidades do PBF na área da saúde, que ambos os sexos não são beneficiados da mesma forma, valendo apenas o acompanhamento do crescimento, desenvolvimento e calendário de vacinação de crianças menores de sete anos e acompanhamento de gestantes e nutrizes, apontando uma lacuna para as crianças acima de 7 anos e, principalmente, para adolescentes do gênero masculino.

Apesar de, muito antes do PBF, o MS instituir o Programa Saúde do Adolescente (PROSAD), este nunca foi implantado como deveria. Vale ressaltar que, na Política Nacional de Atenção Integral à Saúde de Adolescentes e Jovens (PNAISAJ), a adolescência e a juventude abrangem a faixa etária de 10 a 24 anos e, na Política Nacional de Atenção Integral à Saúde do Homem (PNAISH), o foco de atenção aponta para o grupo de homens na faixa etária de 25 a 59 anos $^{(5,6)}$.

O recorte etário realizado pelas Ciências Biológicas, Ciências Políticas, Ciências Jurídicas e Políticas Sociais ignora as características desse segmento populacional nas orientações de práticas sociais, na elaboração de políticas de desenvolvimento coletivo, na investigação epidemiológica e no conhecimento de certas especialidades. Há uma parcela significativa da população adolescente brasileira em torno de $30 \%$ a $33 \%$ da população total ao longo da primeira década do século XXI, segundo fontes do Instituto Brasileiro de Geografia e Estatística (IBGE) - que é negligenciada pela sociedade no que diz respeito à saúde $\mathrm{e}$ participação social ${ }^{(5)}$.

$\mathrm{Na}$ definição das linhas de ação para o atendimento da criança e do adolescente, o Estatuto da Criança e do Adolescente (ECA) destaca as políticas e programas de assistência social, determinando o fortalecimento e a ampliação de benefícios assistenciais e políticas compensatórias como estratégia para redução dos riscos e agravos de saúde dos jovens. Esses são os novos marcos ético-legais que devem nortear as políticas nacionais de atenção à saúde dos jovens no Sistema Único de Saúde ${ }^{(7)}$.

Diante desse contexto, pergunta-se: os beneficiários do Programa Bolsa Família têm conhecimento sobre a condicionante saúde? A saúde pública tem conhecimento sobre a importância dessa condicionante para a nossa população jovem? Acreditamos que a condicionante saúde existe, mas, infelizmente, muito aquém do que realmente a nossa população merece e necessita.

\section{REFERÊNCIAS}

1. Santos HPO, Nascimento MFM. Considerações sobre o programa bolsa família: avanços ou recuos na “proteção social”? Teor Pol e Soc. 2008;1(1):43-50.

2. Ministério do Desenvolvimento Social e Combate à Fome (BR). Programa Bolsa Família [acesso em Ago 2013]. Disponível em: http://www.mds.gov.br/ bolsafamilia.

3. Brasil. Decreto $\mathrm{n}^{\circ} 8232$, de 30 de abril de 2014. Altera o Decreto $\mathrm{n}^{\circ} 5.209$, de 17 de setembro de 2004, que regulamenta o Programa Bolsa Família, e o Decreto $\mathrm{n}^{\mathrm{o}}$ 7.492, de 2 de junho de 2011, que institui o Plano Brasil Sem Miséria. [acesso em Ago 2014]. Disponível em: http://www.planalto.gov.br/ccivil_03/_Ato20112014/2014/Decreto/D8232.htm.

4. Senna MCM, Burlandy L, Monnerat GL, Schottz V, Magalhães R. Programa Bolsa Família: nova institucionalidade no campo da política social brasileira? Rev Katálysis. 2007;10(1):86-94.

5. López SB. Sentimentos atribuídos à adolescência e à juventude em seu entrelaçamento com a masculinidade: uma leitura da PNAISAJ [tese]. Rio de Janeiro: FIOCRUZ/Instituto Fernandes Figueira, 2012.

6. Horta NC, Madeira AMF, Armond LC. Desafios na atenção à saúde do adolescente. In: Borges ALV, Fujimori E. Enfermagem e a saúde do adolescente na atenção básica. São Paulo: Manole, 2009. p. 119-41.

\section{Endereço para correspondência:}

Núbia Maria Uchôa Barbosa

Universidade de Fortaleza

Mestrado de Saúde Coletiva

Av. Washington Soares, 1321

Bairro: Edson Queiroz

CEP: 60.811-905 - Fortaleza - CE - Brasil

E-mail: nuchoabarb@hotmail.com 